\title{
Fruit Derived Potentially Bioactive Bioengineered Silver Nanoparticles
}

\author{
Abu Baker ${ }^{1} *$ \\ Sana $\operatorname{Iram}^{2, *}$ \\ Asad Syed ${ }^{3}$ \\ Abdallah M Elgorban ${ }^{3}$ \\ Ali H Bahkali ${ }^{3}$ \\ Khurshid Ahmad (D) ${ }^{2}$ \\ Mohd Sajid Khan' \\ Jihoe $\mathrm{Kim}^{2}$
}

'Nanomedicine \& Nanobiotechnology Lab, Department of Biosciences, Integral University, Lucknow, 226026, India;

${ }^{2}$ Department of Medical Biotechnology and Research Institute of Cell Culture, Yeungnam University, Gyeongsan, 3854I, Republic of Korea; ${ }^{3}$ Department of Botany and Microbiology, College of Science, King Saud University, Riyadh, I |45I, Saudi Arabia

*These authors contributed equally to this work

\begin{abstract}
Introduction: Protein-derived biogenic syntheses of inorganic nanoparticles have gained immense attention because of their broad spectrum of applications. Proteins offer a reducing environment to enable the synthesis of nanoparticles and encapsulate synthesized nanoparticles and provide them temporal stability in addition to biocompatibility.

Methods: In the present study, Benincasa hispida fruit proteins were used to synthesize silver nanoparticles (AgNPs) at $37{ }^{\circ} \mathrm{C}$ over five days of incubation. The synthesis of AgNPs was confirmed by UV-Vis spectroscopy, TEM, zeta potential, and DLS analyses. Further, these NPs depicted antibacterial and antibiofilm effects. Additionally, the anticancer activities of nanoparticles were also tested against the lung cancer cell line (A549) with respect to the normal cell line (NRK) using MTT assay. Further, the estimation of ROS generation through DCFH-DA staining along with a reduction in mitochondrial membrane potential by Mito Tracker Red CMX staining was carried out. Moreover, nuclear degradation in the AgNPs treated cells was cross-checked by DAPI staining.

Results: The average size of AgNPs was detected to be $27 \pm 1 \mathrm{~nm}$ by TEM analysis, whereas surface encapsulation by protein was determined by FTIR spectroscopy. These NPs were effective against bacterial pathogens such as Escherichia coli, Staphylococcus aureus, Salmonella enteric, and Staphylococcus epidermis with MICs of $148.12 \mu \mathrm{g} / \mathrm{mL}, 165.63$ $\mu \mathrm{g} / \mathrm{mL}, 162.77 \mu \mathrm{g} / \mathrm{mL}$, and $124.88 \mu \mathrm{g} / \mathrm{mL}$, respectively. Furthermore, these nanoparticles inhibit the formation of biofilms of E. coli, S. aureus, S. enteric, and S. epidermis by $71.14 \%$, $73.89 \%, 66.66 \%$, and $64.81 \%$, respectively. Similarly, these nanoparticles were also found to inhibit (IC50 = 57.11 $\mu \mathrm{M})$ the lung cancer cell line (A549). At the same time, they were nontoxic against NRK cells up to a concentration of $200 \mu \mathrm{M}$.
\end{abstract}

Discussion: We successfully synthesized potentially potent antibacterial, antibiofilm and anticancer biogenic AgNPs.

Keywords: AgNPs, green synthesis, Benincasa hispida, antibacterial, antibiofilm, anticancer

\section{Introduction}

The demands of inorganic nanomaterials have been growing massively, and their production will continue to reach 13.7 billion US dollars by $2026 .{ }^{1}$ The broadspectrum role and applications of nanomaterials have contributed immensely to macroeconomic industries. Their demand will continue to rise in developed and developing countries. The production of silver nanoparticles (AgNPs) plays a huge role in this phenomenon. Particularly as a broad-spectrum antimicrobial agent, ${ }^{2}$ AgNPs are currently the most commercialized nano-products. The use of AgNPs has increased a lot in commercial consumer products, such as deodorants, shower gels of NIVEA, and bandages like Elastoplasts for their improved antimicrobial
Correspondence: Mohd Sajid Khan Department of Biosciences, Integral Tel +522-2890812, 6451039;

Tel +522-2890812, 6451039

Fax +522-2890809

Email research.sajid@gmail.com

Jihoe Kim

Department of Medical Biotechnology,

Yeungnam University, Gyeongsan, 3854I,

South Korea

Email kimjihoe@ynu.ac.kr 


\section{Graphical Abstract}

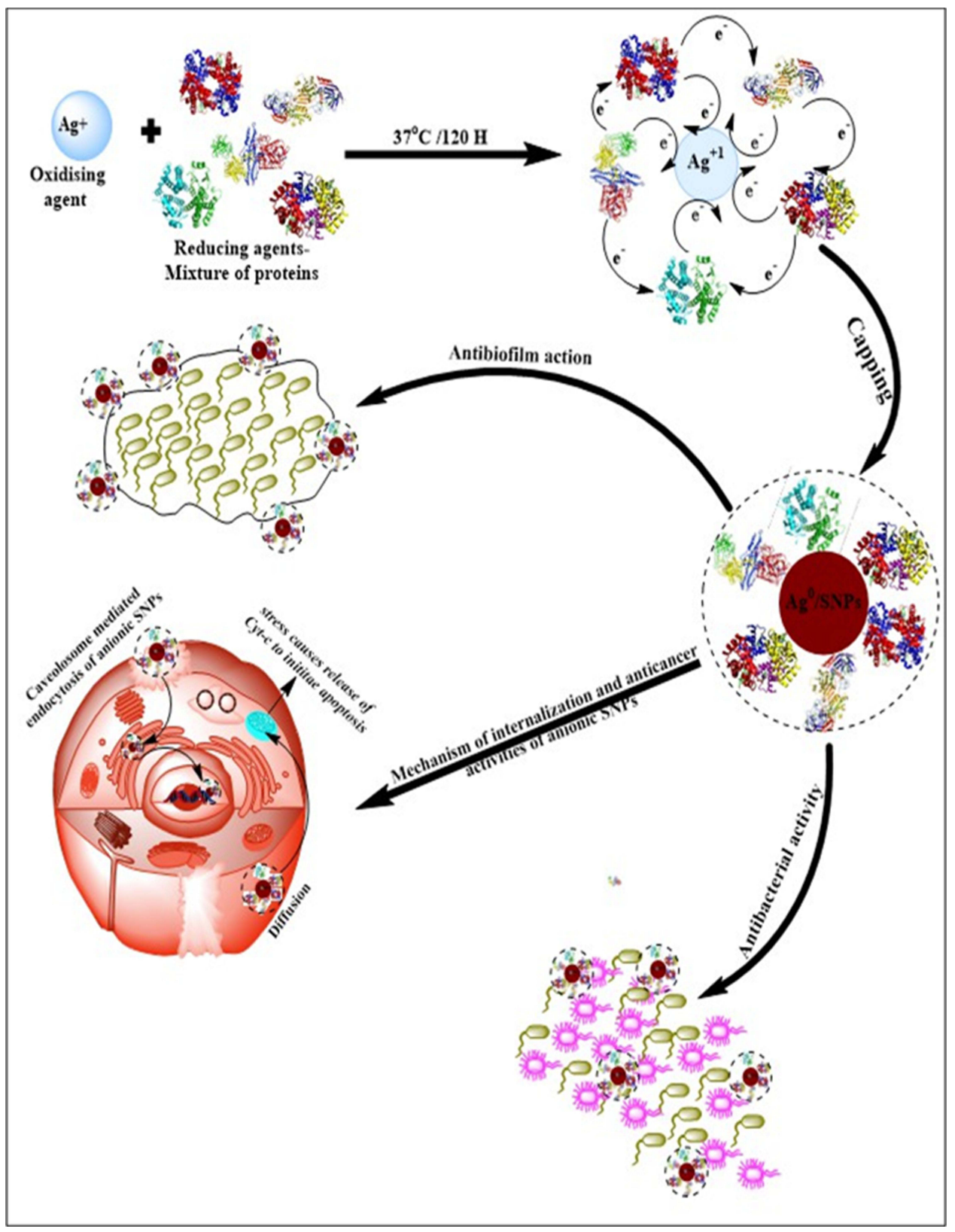

properties. The silver-based brands of wound dressing are also readily available in the market with different compositions, such as Acticoat ${ }^{\mathrm{TM}}$, Mepilex $^{\circledR} \mathrm{Ag}$, Aquacel $^{\circledR}$, Flaminal $^{\circledR}$, Biatain ${ }^{\circledR} \mathrm{Ag}$, SILVERCEL ${ }^{\mathrm{TM}}$ and Allevyn ${ }^{\circledR}$ Ag. ${ }^{3}$ They have been used commercially in various segments, including personal care products, antimicrobial socks, household cleansers, food storage containers, laundry additives, home appliances, paints, and even food supplements. ${ }^{4}$ Physical and chemical methods use severe conditions and toxic chemicals to synthesize nanoparticles since they have their limitations in biological applications.

Thus, the development of eco-friendly methods is the need of the hour. However, using non-toxic reagents to 
produce monodispersed, biocompatible, desired size, and custom functionalized nanoparticles is not an easy task. ${ }^{5}$ Chemically synthesized hydrazine, hydrogen peroxide, sodium borohydride, and sodium citrate mediated AgNPs have antibacterial and anticancer activity but are still not biocompatible and are toxic to the environment and human health. ${ }^{6-8}$ Massive trials have been carried out to accomplish this task by using different types of green types of machinery, including plant-based materials, algae, yeast, fungi, bacteria, and enzymes. ${ }^{9}$ The phytochemicals in these plants can serve as a dual function of reducing and stabilizing agents in synthesizing metal nanoparticles. Functionalized nanoparticles act as a drug carrier or as antibacterial agents. ${ }^{10,11}$ Nanoparticles are also used to deliver photo thermal agents. They are used as nanoparticles themselves or as photo thermal ligands bioconjugated over the surface of nanoparticles. ${ }^{12}$ Graphene-based nanoparticles exhibit antibacterial activity against Streptococcus mutans bacteria. ${ }^{13}$ The biogenic particles have broad-spectrum applications, including eco-friendly and economical production values. Their biological, physical, and chemical properties offer a widespread range of applications such as easy and stable functionalization, high biocompatibility, well-described morphologies, and ease of production and scaling. ${ }^{11}$ Numerous biogenic inorganic nanomaterials have been produced using fungi, including Penicillium fellutanum, ${ }^{12}$ Aspergillus fumigatus, Cladosporium cladosporioides, and Coriolus versicolor, ${ }^{13}$ algae such as Sargassum wightii Greville, ${ }^{14}$ microbial enzymes like acetyl xylan esterase, cellobiohydrolase D, glucosidase and $\beta$-glucosidase, ${ }^{1}$ nitrate reductase,${ }^{15}$ plant extracts like Lysiloma acapulcensis, and Euphorbia wallichii, ${ }^{14}$ the leaf extract of Scoparia dulcis, Bacopa monnieri, ${ }^{15}$ and enzymes such as bromelain, ${ }^{16} \operatorname{trypsin}^{17}$ and papain. ${ }^{18}$

Benincasa (Cucurbitaceae) is a monotypic genus with a single species Benincasa hispida. It is cultivated more or less throughout India and also in warm countries. Traditionally, the fruit of B hispida is used as a diuretic, and the seeds have been documented to exhibit antiangiogenic effects on prostate cells. ${ }^{19}$ The mature fruits of $B$. hispida is an extremely good source of dietary fibers, proteins, enzymes, sterols, flavonoid C-glycoside, phenolic acids, sugars, and trace minerals terpenes, flavonoids, including quercetin, rutin, alkaloids, glycoside (arbutin), coumarin (umbelliferone), vitamin (A, B1, B3, C), amino acids (phenylalanine, tyrosine, and tryptophan) and many more. ${ }^{20}$ The protein includes the osmotin like protein, a member of pathogenesis-related protein, ${ }^{21}$ and two other proteins from the seed, a chitinase with lysozyme activity, ${ }^{21}$ and a biological serine proteinase inhibitor that inhibit important molecules such as trypsin, human leukocyte elastase, and cathepsin $\mathrm{G}^{22}$ The amount of protein is in the range of 0.3 to $0.5 \%$ of an edible portion of fruit pulp. Total protein and free amino acids have concentrations of 216.400 and $92.549 \mathrm{mg} / 100 \mathrm{~g}$ fresh weight, respectively. ${ }^{23}$ It exhibits a wide range of biological activities, such as anti-inflammatory, antipyretic, ${ }^{24}$ neuromodulatory, ${ }^{25}$ anti-aging, ${ }^{26}$ immunomodulatory, hepatoprotective, antidiabetic, ${ }^{27}$ anti-obesity, ${ }^{28}$ antiulcer, ${ }^{29}$ anti-oxidant, ${ }^{30}$ angiotensin-converting enzyme inhibitory, ${ }^{31}$ diuretic, nephroprotective, ${ }^{32} 5 \alpha$-reductase inhibitory/anti-androgenic, anti-angiogenesis ${ }^{33}$ and antimicrobial. ${ }^{34}$ It also inhibits the mRNA expression level of monocyte chemoattractant protein-1 (MCP-1), interleukin-8 (IL-8), and ed NF- $\mathrm{BB}$ activation by blocking the phosphorylation and degradation of its inhibitory protein, I $\mathrm{KB}-\alpha$ in human. ${ }^{35}$ Here, a facile method of green synthesis of AgNPs using B.hispida pulp protein extract has been used for the first time. The proteins simultaneously reduced capped agents (s) and produced highly stable and biocompatible AgNPs. The physical characterization (UV-Vis spectroscopy, TEM, zeta potential, and DLS) confirmed that the nanoparticles were highly effective against biofilm synthesis along with antibacterial activities against Escherichia coli, Staphylococcus aureus, Salmonella enterica, and Staphylococcus epidermidis. They showed promising anticancer potential against lung cancer cell line A549. Though, AgNPs were significantly non-toxic against normal cell line NRK.

\section{Methods}

\section{Extraction of B. hispida Fruit Protein}

A total of $5 \mathrm{~g}$ of $B$. hispida fresh fruit were taken and washed meticulously with distilled water to remove dust particles. They were then finely ground using liquid nitrogen. Tris $\mathrm{HCl}$ buffer $(0.1 \mathrm{M}, \mathrm{pH} 7.5)$ was used to homogenize the powdered samples. The clear and transparent solution was subjected to $95 \%$ ammonium sulfate precipitation to obtain the maximum extracted proteins. The given equation was used to calculate the exact amount of ammonium sulfate salt for the deluge of proteins: 


$$
\begin{gathered}
\text { Weight }(g)=\frac{G_{\text {sat }}(S 2-S 1)}{1-(P S 2)} \\
P=\frac{\text { Sp.Vol.x } G_{\text {sat }}}{1000}
\end{gathered}
$$

Where $G_{\text {sat }}$ denotes the weight (in gm) of ammonium sulfate in one of the saturated solutions, S1 \& S2 are the fractions of complete saturation. ${ }^{36}$ The ammonium sulfate precipitation was carried out by adding a calculated amount of salt, pinch by the pinch (to avoid an increase in local concentration), into the fixed volume of protein solution. The whole process was performed in ice-cold condition with continuous stirring, and the solution was permitted to retain at $4^{\circ} \mathrm{C}$ overnight. The protein extract of B. hispida fruit was centrifuged for $20 \mathrm{~min}$ at $20,000 \mathrm{rpm}$ after complete precipitation, and the acquired residue was dissolved in $400 \mu \mathrm{L}$ of PBS (50 mM, pH 7.5, $4{ }^{\circ} \mathrm{C}$ ). Now the purified protein extract was used for the synthesis of AgNPs. Bradford assay was used to determine the protein concentration, and the purified proteins were analyzed on 7.5\% SDS-PAGE and stained with Coomassie brilliant blue stain.

\section{In vitro Synthesis of Silver Nanoparticles}

A $3 \mathrm{~mL}$ reaction mixture in PBS $(50 \mathrm{mM}, \mathrm{pH} 7.5)$ consisting of numerous concentrations of $B$. hispida fruit proteins $(0.33,0.5,1,1.5$ and $2 \mathrm{mg}$ ), and $1.0 \mathrm{mM}$ silver nitrate salt at different temperatures $(37,40,60,80$, and $\left.100^{\circ} \mathrm{C}\right)$ was incubated at different time intervals $(1,2,3$, 4, 5 days). Desired-sized nanoparticles were attained at 37 ${ }^{\circ} \mathrm{C}$ and $0.33 \mathrm{mg} / \mathrm{mL}$ protein concentration after five days of incubation. Centrifugation was performed at 30,000 $\mathrm{g}$ for $30 \mathrm{~min}$ after the termination of the reaction to collect and wash the AgNPs twice in Milli Q water. Ultimately, to precipitate unbound protein and impurities present in the reaction mixture $50 \% \mathrm{v} / \mathrm{v}$ ethanol was used, and the resulting AgNPs were used for further analyses. ${ }^{37}$

\section{Characterization of Bioengineered Silver} Nanoparticles

\section{Optical Properties Determination by UV-Visible Spectroscopy}

UV-Visible spectroscopic measurements were made in a quartz cuvette with a resolution of $1 \mathrm{~nm}$ using A Shimadzu dual-beam Spectrophotometer (model UV1601 PC). The absorption spectra were collected at wavelengths ranging from 200 to $800 \mathrm{~nm}$. The sample's optical densities were measured and graphically studied.

\section{Hydrodynamic Size Determination by Dynamic Light Scattering (DLS)}

A DLS particle size analyzer (Zetasizer Nano-ZS, Model number: ZEN3600, Malvern Instruments Ltd, Malvern, UK) was used to determine the average particle size of AgNPs. The sample was placed in a $1.5-\mathrm{mL}$ low-volume disposable cuvette (DTS0112) and calibrated to a $0.5 \% \mathrm{wt} /$ vol concentration in deionized water before sonication for $1 \mathrm{~min}$. The average of three measurements per sample was used to calculate the mean particle size. ${ }^{38}$

\section{Size Determination by Transmission Electron Microscopy (TEM)}

TEM was performed using carbon-coated TEM copper grids and a drop of AgNPs solution. The Tecnai TM G2 Spirit BioTWIN (FEI Company) running at an accelerating voltage of $80 \mathrm{kV}$ was used for TEM. ${ }^{38}$

\section{Charge Determination by Zeta Potential}

The zeta potential of nanoparticles in a solution is a measure of their colloidal stability. Zeta potential can also determine the concentration distribution of nanoparticles and the shielding/exposure of charged groups as they either set or carry the charge of their capping agent. It was performed with the help of the Zetasizer Nano-ZS (Model ZEN3600, Malvern Instruments Ltd, Malvern, UK). ${ }^{38}$

\section{Surface Characterization by Fourier-Transform Infrared Spectroscopy (FTIR)}

The FTIR technique reveals information on protein-nanoparticle associations. In both native and bioconjugated proteins, FTIR can provide a comprehensive evaluation of functional groups. The purpose of FTIR was to determine how much light was absorbed by the samples at each wavelength. Therefore, it confirms the presence of protein on nanoparticles.

\section{Determination of Antibacterial Activity of Silver Nanoparticles}

The agar well diffusion technique was performed to assess the biogenic nanoparticles initial antibacterial activity against S. aureus, E. coli, S. enteric, and S. epidermis. ${ }^{39}$ The bacterial isolates were grown in nutrient broth for $24 \mathrm{~h}$ at $37^{\circ} \mathrm{C}$ with 180rpm agitation. Wells were bored with PBS (as a control) and AgNPs, as a preliminary qualitative test. The plates were checked for the inhibitory effect of AgNPs on bacterial growth after $24 \mathrm{~h}$ of incubation at $37{ }^{\circ} \mathrm{C}$, as demonstrated by a clear area surrounded by the well. 


\section{Determination of Minimum Inhibitory Concentration (MIC)}

The MIC of AgNPs was further determined by using the broth dilution method against $S$. aureus, E. coli, S.enteric, and $S$. epidermis. ${ }^{40}$ Bacterial strains in a mid-logarithmic phase were collected and diluted to $2 \times 10^{5}$-forming units per $\mathrm{mL}(\mathrm{CFU} / \mathrm{mL})$ in PBS with $0.03 \%$ Luria-Bertani (LB) broth. The AgNPs were repeatedly diluted in $100 \mu \mathrm{L}$ of LB medium in 96-well microtiter plates following the method reported elsewhere. ${ }^{39}$ The MIC-50 and MIC-75 were accredited to the low concentrations of AgNPs that reduced microbial growth by $50 \%$ and $75 \%$, respectively. For each experiment, autoclaved water was used as a negative control.

\section{Determination of Anti-Biofilm Potential of Silver Nanoparicles}

The AgNPs antibiofilm potential efficacy was analyzed as the biofilm formation by 96 well plate microtiter methods. ${ }^{41}$ Each microtiter plate well is filled with $190 \mu \mathrm{L}$ of nutrient broth media and $10 \mu \mathrm{L}$ of freshly prepared bacterial culture of S. aureus, E. coli, S. enteric, and S. epidermis. The IC-50 and IC-75 concentrations of AgNPs are added to the mixture of each respective bacteria. The substance of each well is discarded and washed two times with PBS of $\mathrm{pH} 7.2$ to evacuate planktonic bacteria after the incubation of the plate at $37^{\circ} \mathrm{C}$ for $24 \mathrm{~h}$. The biofilm arrangement around the walls of a plate by adherent sessile organisms, fixed by sodium acetate of $2.5 \%, \mathrm{w} / \mathrm{v}$, and $0.25 \%$, w $/ \mathrm{v}$ of crystal violet dye, is used to stain the biofilm, which is rinsed with Milli-Q water to eradicate the surplus stain and incubated at room temperature for drying. Later, $100 \mu \mathrm{L}$ of DMSO was added to each dried well, and the absorbance was measured at $620 \mathrm{~nm}$ on an ELISA plate reader (Multiskan ${ }^{\circledR}$ EX, Thermo Scientific, Finland). The absorbance values obtained are used as the indicator of adhering bacteria around the surface of the wall of each well for the biofilm formation. The percentage inhibition of biofilm was calculated by using the below equation. Each experiment was done in triplicate, and the AgNPs free cultures of each bacterium served as a positive control.

AgNPs biofilminhibition $\%$

$=1-\left(\frac{\text { Absorbance of SNPstreatedcells at } 620 \mathrm{~nm}}{\text { Absorbance of untreatedcontrolcells at } 620 \mathrm{~nm}}\right) \times 100$

\section{Evaluation of Anticancer Potential of Silver Nanoparticles}

A549 and NRK cells were seeded $\left(5 \times 10^{3}\right.$ cells $)$ in each well of 96 well plates and incubated for $24 \mathrm{~h}$ in a humidified $\mathrm{CO}_{2}(5 \%)$ incubator at $37{ }^{\circ} \mathrm{C}$. Ultimately, the cells were treated with various concentrations of AgNPs $(25,50,75,100,125,150,175, \mu \mathrm{M})$ in triplicate and further incubated for the next $24 \mathrm{~h}$. Later, after the incubation, the media was discarded and 10 $\mu \mathrm{L}$ MTT [3-(4,5-dimethylthiazol-2-yl)-2,5-diphenyltetrazolium bromide] ( $5 \mathrm{mg} / \mathrm{mL}$ in PBS), was added to each well. Further, the plate was incubated for 2 $\mathrm{H}$ in a $5 \% \mathrm{CO}_{2}$ incubator. Moreover, formazan crystals were solubilized in $100 \mu \mathrm{L}$ DMSO (Dimethyl sulfoxide), and their optical densities were measured at 570 $\mathrm{nm}$ wavelength by utilizing an ELISA reader (Microplate Reader (BIORAD-680).

\section{Study of Cytomorphological Changes of Silver Nanoparticles Treated A549 Cells}

The A549 cells were pre-treated with numerous concentrations $\left(\mathrm{IC}_{25}, \mathrm{IC}_{50}\right.$, and $\left.\mathrm{IC}_{75}\right)$ of $\mathrm{AgNPs}$ at $37{ }^{\circ} \mathrm{C}$ in a $\mathrm{CO}_{2}$ $(5 \%)$ environment for $24 \mathrm{H}$. The net morphological variations of treated cells were studied under an inverted phasecontrast microscope (Nikon ECLIPSE Ti-S, Nikon Corporation, Tokyo, Japan).

\section{Study of Variations in Nuclear Morphology of Cells}

The effect of AgNPs on the genetic materials of A549 cells was examined with the help of fluorescent nuclear dye DAPI. The cells were incubated with $4 \%$ paraformaldehyde for $10 \mathrm{~min}$ after washing the seeded cells with PBS buffer. Ultimately, these treated cells were permeabilized with permeabilizing buffer (3\% paraformaldehyde and $0.5 \%$ Triton X-100) and stained by fluorescent dye DAPI. The fluorescence microscope was used to capture the images of the stained cells. The cells with fragmented and condensed nuclei had been considered apoptotic cells.

\section{Estimation of Mitochondrial Membrane Potential Under Mito Tracker Red Staining}

The change in mitochondrial membrane potential under AgNPs over A549 cells was examined by Mito Tracker Red CMX Ros dye. Briefly, AgNPs were incubated with A549 cells $\left(5 \times 10^{3}\right.$ cells/well $)$ for $24 \mathrm{~h}$ at $\mathrm{IC}_{50}$ and again further incubated for $24 \mathrm{~h}$. Ultimately, the media was decanted, and cells were incubated with $200 \mu \mathrm{L}(300 \mathrm{nM})$ Mito Tracker dye for $45 \mathrm{~min}$ at $37^{\circ} \mathrm{C}$ in the dark, followed by three times washing with PBS. The fluorescence microscope (evosFLc) with a texas red filter having an excitation wavelength of $579 \mathrm{~nm}$ and an emission wavelength of $599 \mathrm{~nm}$ was used to carry out the imaging of the cells. The fluorescence 
intensity of mitochondrial content was quantified using Image-J software.

\section{Quantification and Detection of Production of Reactive Oxygen Species (ROS)}

Generation of ROS in AgNPs treated A549 cells were determined under the fluorescence microscope. The observation was based on the following factors such as fluorescence of a fluorogenic marker, 5-(and 6)-carboxy $-2^{\prime}, 7^{\prime}$-dichlorodihydrofluorescein diacetate (carboxy-
$\mathrm{H}_{2}$ DCFDA $)$ in viable cells. The cells $\left(5 \times 10^{3}\right.$ in each well) were seeded into 24 -well culture plates and incubated for $24 \mathrm{~h}$ inside the $\mathrm{CO}_{2}(5 \%)$ incubator at $37{ }^{\circ} \mathrm{C}$. Later, the cells were incubated with AgNPs for 24 h. Ultimately, cells were incubated with $\mathrm{H}_{2}$ DCFDA (10 $\mu \mathrm{M}$ ) for $30 \mathrm{~min}$ at $37^{\circ} \mathrm{C}$, and other cells were supplemented with $200 \mu \mathrm{L}$ of phosphate buffer saline (PBS) in every well. These plates were kept on a shaker for the next $10 \mathrm{~min}$ at room temperature. The fluorescence of

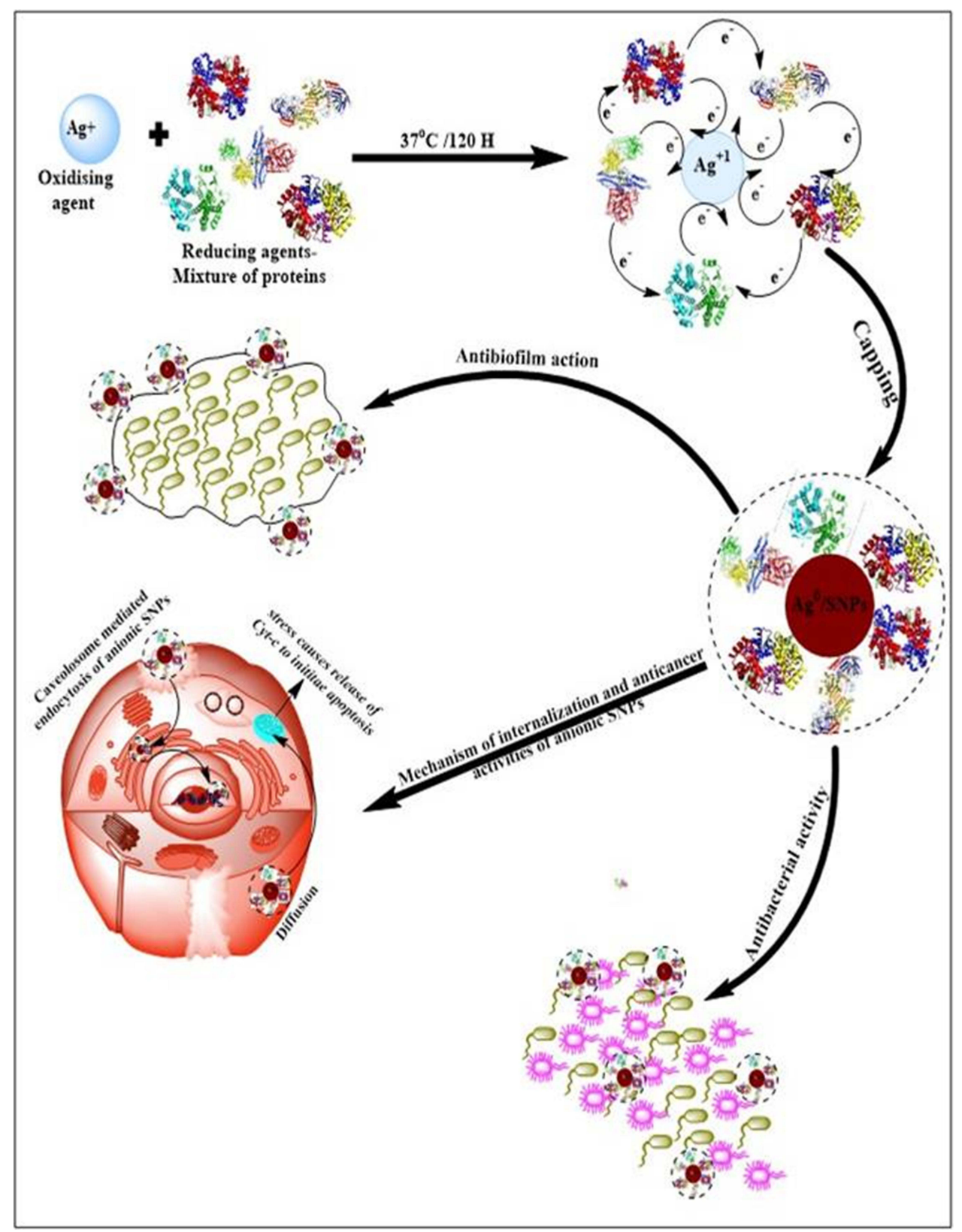

Figure I Schematic representation of the mechanism of B. hispica fruit proteins mediated synthesis of biogenic AgNPs and their roles in anticancer, antibacterial, and antibiofilm agents. 
cells was determined by using a magnifying lens (fluorescence microscope evosFLc). Quantification of cellular fluorescence from fluorescence microscopy images was performed by ImageJ software.

\section{Statistical Analysis}

As described previously, all statistical analyses were carried out using the Origin 6.0 software (USA), as described previously. ${ }^{42}$

\section{Results and Discussion}

Synthesis of Fruit Derived Bioengineered Silver Nanoparticles

Proteins are significantly bigger to encapsulate the nanoparticles and provide them with stability. Apart from size, the native charge of proteins also plays a key role in nanoemulsion stability, providing a specific charge to particles and dictating their internalization mode, which is critical in drug delivery systems (Figure 1). The proteins
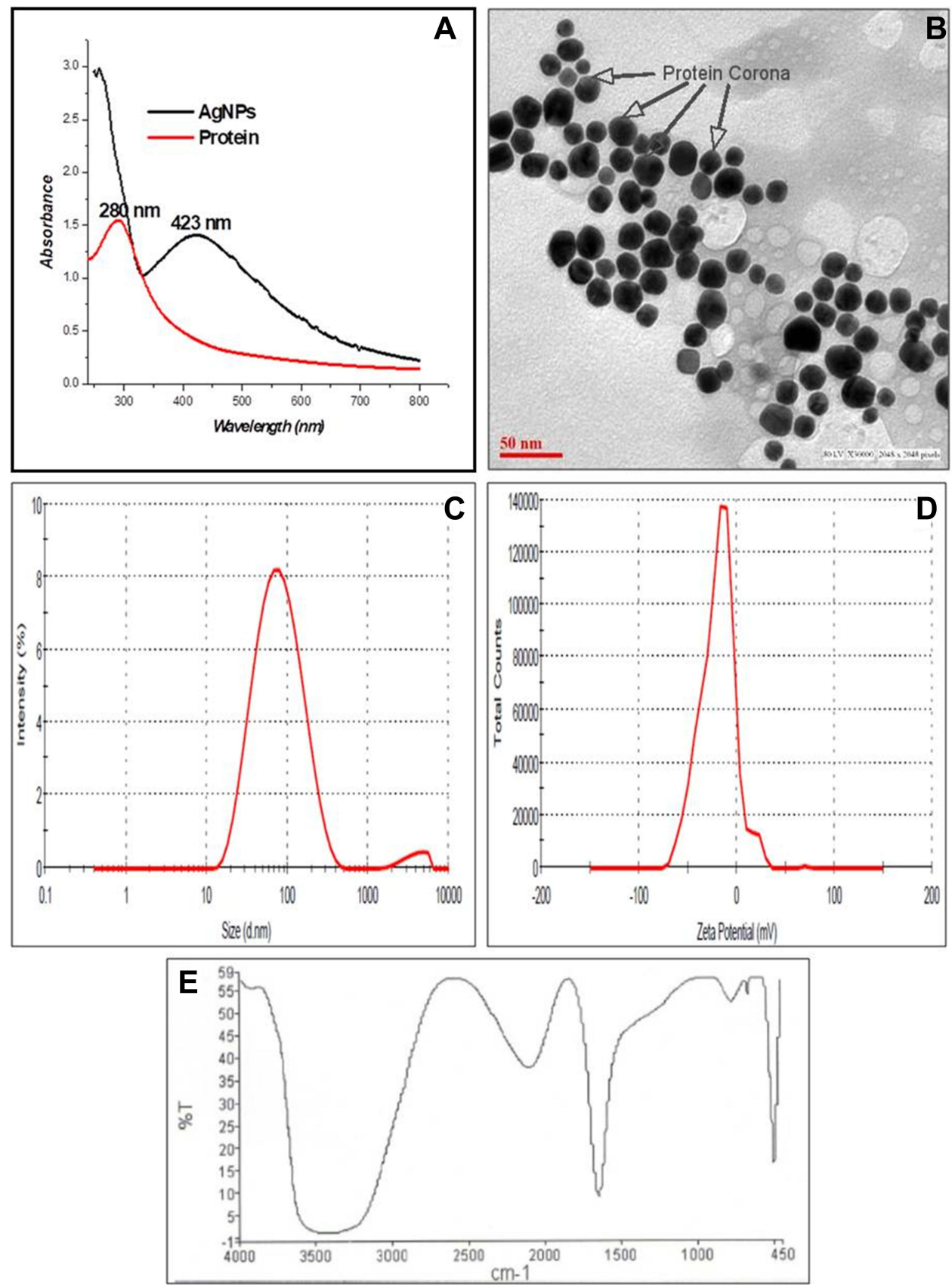

Figure 2 Characterization of B. hispida fruit proteins mediated synthesis of AgNPs by physical techniques: (A) UV-visible spectrum, (B) TEM Micrograph with light gray protein Corona mark by an arrow, (C) size distribution by DLS (D) zeta potential (E) surface characterization by FTIR spectrum. 
undergo conformational changes due to the rapid exchange of electrons among protein(s) and metal ions while synthesizing the nanoparticles. Here, with the progress of synthesis, the silver ion $\left(\mathrm{Ag}^{+}\right)$changes into a neutral $\left(\mathrm{Ag}^{0}\right)$ form, restoring the native conformation of proteins. However, in some proteins, few secondary and fewer tertiary structures cannot be restored. The AgNPs were synthesized by incubatinghispida fruit proteins $(0.33 \mathrm{mg} / \mathrm{mL}$ protein $)$ with 1.0 $\mathrm{mM}$ silver nitrate salt at $37^{\circ} \mathrm{C}$ for five days. Numerous reactions in the combinations of different temperatures (size of AgNPs increase with decrease instability by increasing the reaction temperature $)^{37}$ and other incubation times were done to standardize the synthesis of desired sized AgNPs. In an aqueous medium, fruit protein extract develops sufficient reduction potential, reducing the $\mathrm{AgNO}_{3}$ with oxidation state " +1 " to $\mathrm{Ag}$ oxidation state " 0 ". This reduction of $\mathrm{AgNo}_{3}$ to $\mathrm{Ag}$ is due to the synergistic effect of various proteins and reducing enzymes such as serine proteases and angiotensin-converting enzyme $(\mathrm{ACE})^{45}$ present in the fruit protein extract. A reaction without salt confirmed the efficacy of fruit protein extract during the synthesis of AgNPs. Moreover, when fruit protein extract was incubated alone with distilled water, it displayed no distinct assimilation peak(s) for AgNPs. The characteristic surface plasmon resonance (SPR) bands of AgNPs and fruit proteins have been noted in absorption spectra and found at $423 \mathrm{~nm}$ and $280 \mathrm{~nm}$, respectively (Figure 2A). TEM analysis has been used to determine the average size of NPS, which was found to be $27 \pm 1$ $\mathrm{nm}$ (Figure 2B) and distinctly separated from each other. A Gatan Digital Micrograph was used to analyze further the TEM micrographs, which exhibited that synthesized AgNPs are almost spherical shaped. DLS confirms the single population of NPs, and hydrodynamic radii of these NPs were found to be $57.03 \mathrm{~nm}$ (Figure 2C). Zeta potential measurements can gauze the long-term stability of NPs. The value of zeta potential for AgNPs was $-19.7 \pm 0.2$ $\mathrm{mV}$ (Figure 2D). The negative value indicates the presence of negatively charged species on the surface of AgNPs generates repulsive forces between particles and restricts the chances of aggregation. It was noticed that these NPs were highly stable because NPs with mediocre zeta potential can be stable due to the lower value of the Hamaker constant. $^{43}$ Fourier transform infrared spectral analysis (Figure 2E) of AgNPs exhibited peaks centered at
$1642.77 \mathrm{~cm}^{-1}$ characteristics of $\mathrm{C}=\mathrm{O}$ of amide groups of the amide I linkage. The bands of amides I exist due to carboxyl stretch and $\mathrm{N}-\mathrm{H}$ deformation vibrations in the amide bond of the proteins, which encapsulated AgNPs. ${ }^{44,45}$ Additionally, the peak at $3431.01 \mathrm{~cm}^{-1}$ confirms the $\mathrm{N}-\mathrm{H}$ stretching vibration. This vibration mode does not depend on the backbone conformation but is very delicate to the strength of a hydrogen bond. Due to various secondary metabolites, a peak at $2106.24 \mathrm{~cm}^{-1}$ represents the $\mathrm{C} \equiv \mathrm{C}$ stretch of alkynes.

\section{Antibacterial Activities of Silver Nanoparticles}

The antibacterial activity of AgNPs has been determined against the four types of bacteria (Figure 3). The $\mathrm{MIC}_{50}$ values were noted against $E$. coli $(148.12 \mu \mathrm{g} / \mathrm{mL})$, S. aureus $(165.63 \mu \mathrm{g} / \mathrm{mL})$, S. enteric $(162.77 \mu \mathrm{g} / \mathrm{mL})$ and S. epidermis $(124.88 \mu \mathrm{g} / \mathrm{mL})$, signifying its broad-spectrum nature. Peel extract of Benincasa hispida AgNPs has antibacterial activity. ${ }^{45}$ In contrast, in our research, pulp protein is used to synthesize AgNPs without toxic chemicals. Silver has enjoyed being the inorganic antibacterial agent of choice to fight against infections and spoilage since ancient times. The antibacterial properties of silver NPs, which make it an ideal biocidal agent, are thought to be due to the slow oxidation shown by silver following the liberation of monovalent silver ion $\left(\mathrm{Ag}^{+}\right)$into the environment. ${ }^{46}$ In general, the interaction of AgNPs with bacterial cells occurs through several mechanisms, including generation ROS by AgNPs, which, when they come in contact with the bacteria, further damages

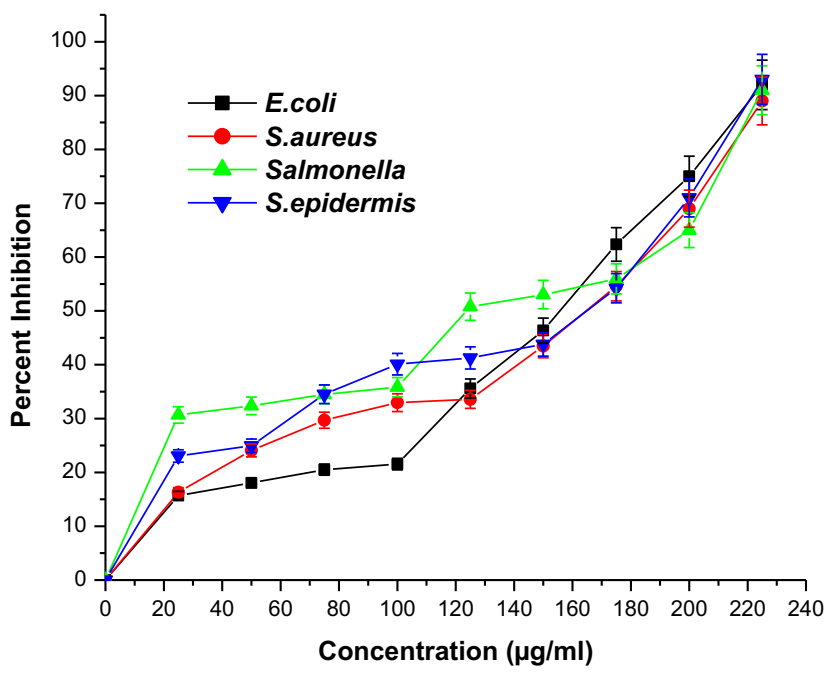

Figure 3 Graph showing the antibacterial potential of silver nanoparticles. All the data were expressed in mean $\pm S D$ of three experiments. 
the cell membrane. Their electrostatic interaction between negatively charged species is present on bacteria's cell membrane, such as amino, carboxyl, and phosphate groups. They are also positively charged species on $\mathrm{Ag}+$ ions and thus cause a change in the cell membranes' structure and making it porous. Additionally, the AgNPs can interact with thiol proteins present on the cell wall and also form complexes electronic donors having nitrogen, phosphorus, oxygen, or sulfur atoms.

Additionally, AgNPs can cause a change in membrane fluidity, enhanced permeability, and membrane integrity loss by disturbing the trans/cis ratio of unsaturated membrane fatty acids. AgNPs can also interrupt the actin cytoskeletal network of bacteria and induce apoptosis in the bacterial cell. ${ }^{47} \mathrm{AgNPs}$ can also bind with the 30S subunit of ribosomes, which results in the deactivation of the ribosome complex, and inhibit protein synthesis. Also, AgNPs can cause a reduction in the expression of proteins such as maltose transporter, fructose bisphosphate aldolase, succinyl coenzyme A synthetase, and $30 \mathrm{~S}$ ribosomal subunit proteins. ${ }^{48}$

It can also disturb RNA transcription, purines, pyrimidines, fatty acids, oxidase, and NADH-succinate dehydrogenase, of bacteria. ${ }^{49}$ They can modulate cellular signaling by dephosphorylating tyrosine residues and activate $\mathrm{p} 53$ protein to inhibit microbial growth. ${ }^{50}$ The most commonly known microbicidal mechanism of AgNPs is that they create pits in
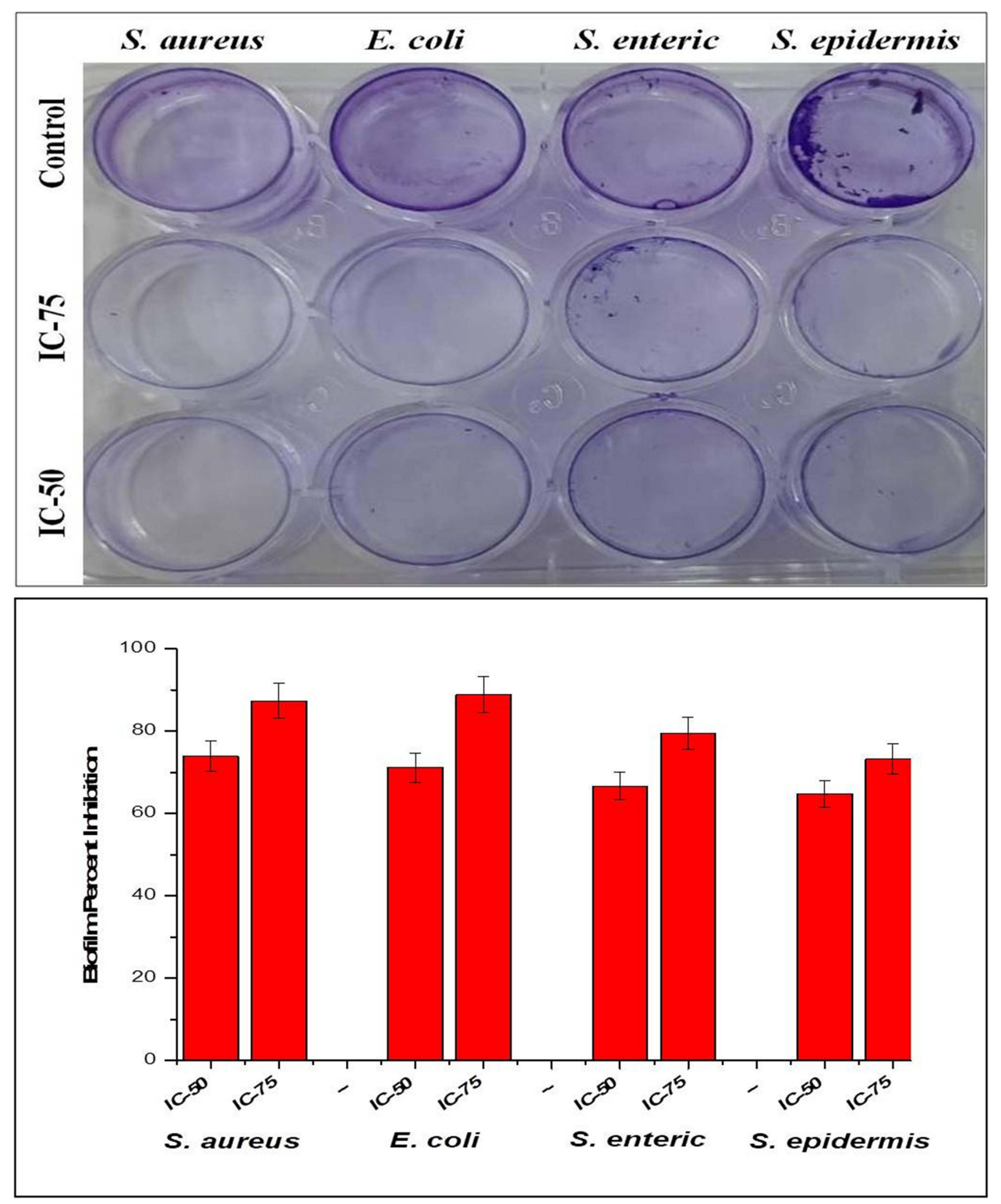

Figure 4 Image and graph showing inhibition of biofilm formation of silver nanoparticles. All the data were expressed in the mean \pm SD of three experiments. 
the cell membrane, which results in the loss of subcellular materials. The Gram-positive (G+) and Gram-negative (G-) bacterial cells act differently when exposed to metal NPs. ${ }^{56}$ The current mechanism known for generating "pits" in the cell membrane by AgNPs is that they target both primary and secondary ( $\alpha$-helix) structures of the cell wall by creating a connection to glycan and peptide ports of the bacterial cell wall. AgNPs connect to the $\beta-1 / 4$ bonds of $\mathrm{N}$-acetylglucosamine and $\mathrm{N}$-acetylmuramic acid of glycan strands, destroying their linkage and discharging them into the growing environment. ${ }^{51}$ The AgNPs use water-filled porins present in the outer membrane to penetrate the G-bacterial cell wall. The G-bacteria are more sensitive toward AgNPs due to the presence of negatively charged lipopolysaccharides.

\section{The Anti-Biofilm Potential of Silver Nanoparticles}

As per the National Institute of Health (NIH), $80 \%$ of infectious diseases are caused by microbial biofilm formation. Both Gram-negative and Gram-positive bacteria can form biofilms. ${ }^{52}$ Biosynthesized AgNPs can hinder biofilm formation of various pathogenic bacteria, and among these, some of them, including $S$. aureus, E. coli, $S$. enteric, and $S$. epidermis, were tested. Bacteria were grown in 96 well plates for the biofilm formation with and without AgNPs for $24 \mathrm{~h}$. There was no reduction in the biofilm formation found in the positive control (without AgNPs treatment).

In contrast, the treatment with AgNPs of concentration IC-50, IC-75 to each bacterial biofilm formation depicted a significant reduction of 70-90\% (Figure 4). The cutbacks in biofilm formation were dose-dependent, and with an increase in the concentration of AgNPs, the biofilm formation decreased. The AgNPs treated at a concentration of IC50 , IC-75 to $S$. aureus biofilm formation decreased by $73.89 \%, 87.36 \%$, E. coli biofilm formation decreased by $71.14 \%, 88.85 \%$, S. enteric biofilm formation decreased by $66.66 \%, 79.41 \%$, and in the case of $S$. epidermis biofilm formation decreased by $64.81 \%, 73.14 \%$, respectively. The antibiofilm potential of AgNPs depends on various factors like the size and shape of nanoparticles, which affect the penetration limit and rely on the affinity between AgNPs and biofilms. ${ }^{53}$ Some other mechanisms are also accountable for biofilm inhibition, such as biosorption and bacterial polysaccharides synthesis inhibition by AgNPs, which is involved in biofilm formation. ${ }^{41}$ The above result confirms that AgNPs have antibiofilm potential against biofilm produced by $S$. aureus, $E$. coli, $S$. enteric, and $S$. epidermis. This means that AgNPs are biofilmdistracting agents. It has been stated that more than 70 species of Gram-negative bacteria communicate and control their population density and mobility via the $\mathrm{N}$-acyl homo serine lactones (AHLs) mediated quorum sensing and the represented AHLs acts as a potential target against biofilm formation. ${ }^{54}$ Inhibition of glucosyltransferase enzyme is also one of the ways to inhibit biofilm formation in different bacterial species. It is known that $E$. coli uses $\mathrm{N}$-acetylneuraminate lyase (NanA), whereas $S$. aureus utilizes the surface protein $\mathrm{G}$ (SasG) for biofilm formation along with GlmU, a bifunctional enzyme with acetyltransferase activity involved in the biosynthesis of Uridine
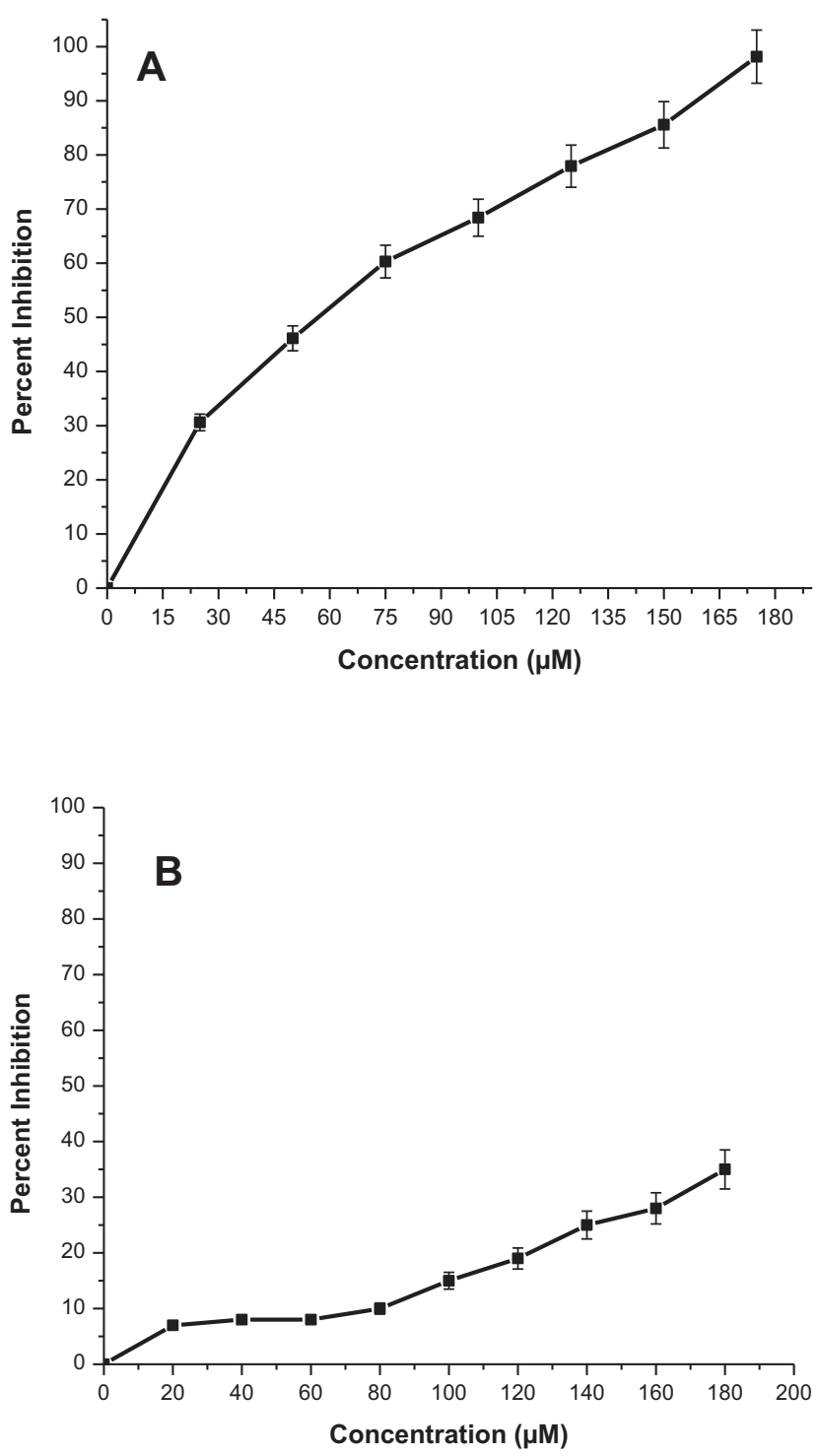

Figure 5 The cytotoxicity study graph of MTT assay for AgNPs treatment against (A) A549 cells and (B) NRK cells. 
diphosphate N-acetylglucosamine (UDP-GlcNAc), which is a key precursor of a $\beta-1,6-\mathrm{N}$-acetyl-D-glucosamine polysaccharide adhesin required for biofilm formation. ${ }^{55}$ Similarly, S. enteric exploits the WrbA, a flavin mononucleotide-dependent NADH:quinone oxidoreductase from the same, and $S$. epidermis takes advantage of poly$\mathrm{N}$-acetylglucosamine (PNA) and polysaccharide intercellular adhesin (PIA) for biofilm formation which works through icaADBC operon. Hence, the as-synthesized AgNPs were prominent inhibitors of the given molecules responsible for biofilm formation.

\section{Anticancer Studies of Silver Nanoparticles Treated A549 Cells, NRK Cells, and Their Cytomorphological Changes}

The AgNPs were highly active against A549 cells (Figure 5A), while they did not show any significant activity against NRK cells up to $200 \mu \mathrm{M}$ (Figure 5B). The anticancer effect is dose-dependent and increases with an increase in the concentration of AgNPs. The $\mathrm{IC}_{50}$ values of AgNPs on A549 were found to be 57.11 $\mu \mathrm{M}$ (Figure 5A). The morphological changes in A549 cells were seen after incubation with different concentrations $\left(\mathrm{IC}_{25}, \mathrm{IC}_{50} \& \mathrm{IC}_{75}\right)$ of AgNPs under phase-contrast microscopy (Figure 6) of untreated cells. The control cells were noticed to be uniformly spread and depicted no distinct or remarkable changes in morphology after $24 \mathrm{~h}$ of incubation (Figure 6A). However, deformed morphologies were irregular, shrunken, necrotic, and detached from the well surface; some cells were noticed to keep their plasma membrane intact, depicting that apoptosis had started in A549 cells treated with AgNPs (Figure 6B-D).

The cytotoxic properties of AgNPs and silvercontaining hybrid nanomaterials may rest on the cell types. AgNPs acts by stopping the cell propagation at subG1 cell cycle. ${ }^{56}$ The improved generation of ROS by exposure of these particles is shown to activate signaling pathways responsible for apoptosis. ${ }^{57}$ It can damage the mitochondrial membrane and further cause irrevocable cell damage. It has also been stated that the process of apoptosis can be understood via the degradation of lysosomes during autophagy, increasing programmed cancer cell death. The activation of caspase- 3 and condensation/fragmentation of chromatin were also the manifestation seen in
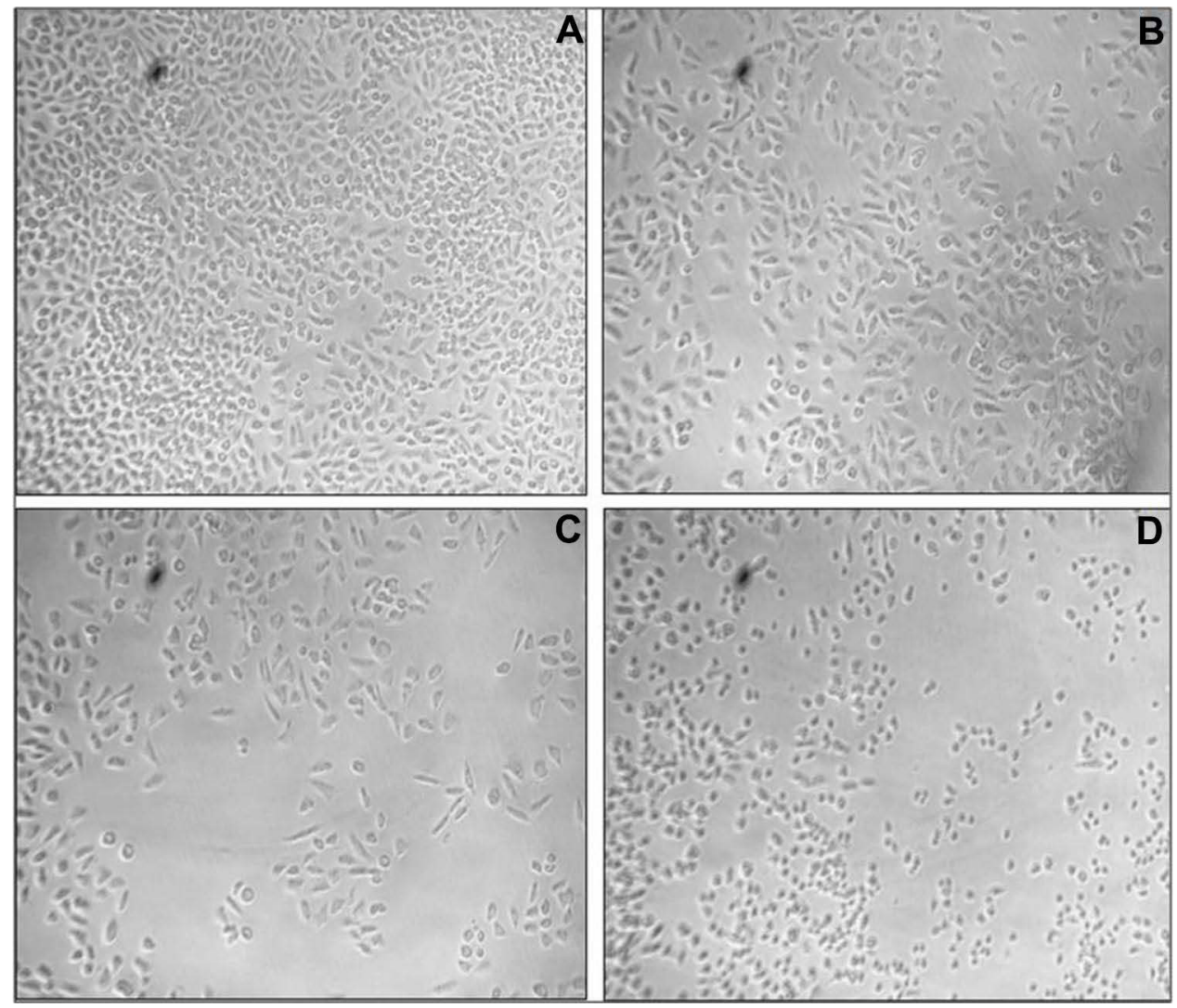

Figure 6 The cytomorphological study of AgNPs treated A549 cells (A) control, (B) IC 25 (C) IC 50 , (D) IC 75 at $20 \times$ magnification. 
AgNPs treated cells, which led to cell death due to the apoptotic process. ${ }^{58}$ AgNPs are the most capable anticarcinogenic agents because of their low toxicity and highly significant anti-carcinogenic properties.

\section{Effect of Silver Nanoparticles on Nuclear Morphology of A549}

The interaction of AgNPs with nuclear materials was examined with the help of fluorescent dye (4',6-diamidino-2-phenylindole) DAPI. Hence, it also confirms the internalization of particles into the nucleus. It is a known fact that anionic nanoparticles follow caveolae-mediated endocytosis and reach into the nucleus without interacting with lysosomes. The AgNPs $\left(\mathrm{IC}_{50} 57.11 \mu \mathrm{m}\right)$ treated

A549 cells were incubated for $24 \mathrm{~h}$ at $37{ }^{\circ} \mathrm{C}$ and stained with DAPI dye. The AgNPs treated cells were found to have an apoptotic impact on A549 cells (Figure 7A and B) compared with untreated cells. The ImageJ software was used to quantify treated and control cells; AgNPs produced more fluorescence than the untreated cells (Figure 8A).

\section{Estimation of Mitochondrial Membrane Potential of Silver Nanoparticles Treated A549 Cells}

The intrinsic apoptosis initiated the release of Cyt-c after the loss of mitochondrial membrane potential $(\Delta \Psi \mathrm{m})$. It was noticed that AgNPs could disrupt the $\Delta \Psi \mathrm{m}$ of A549 cells, and it was projected by potential-dependent dye
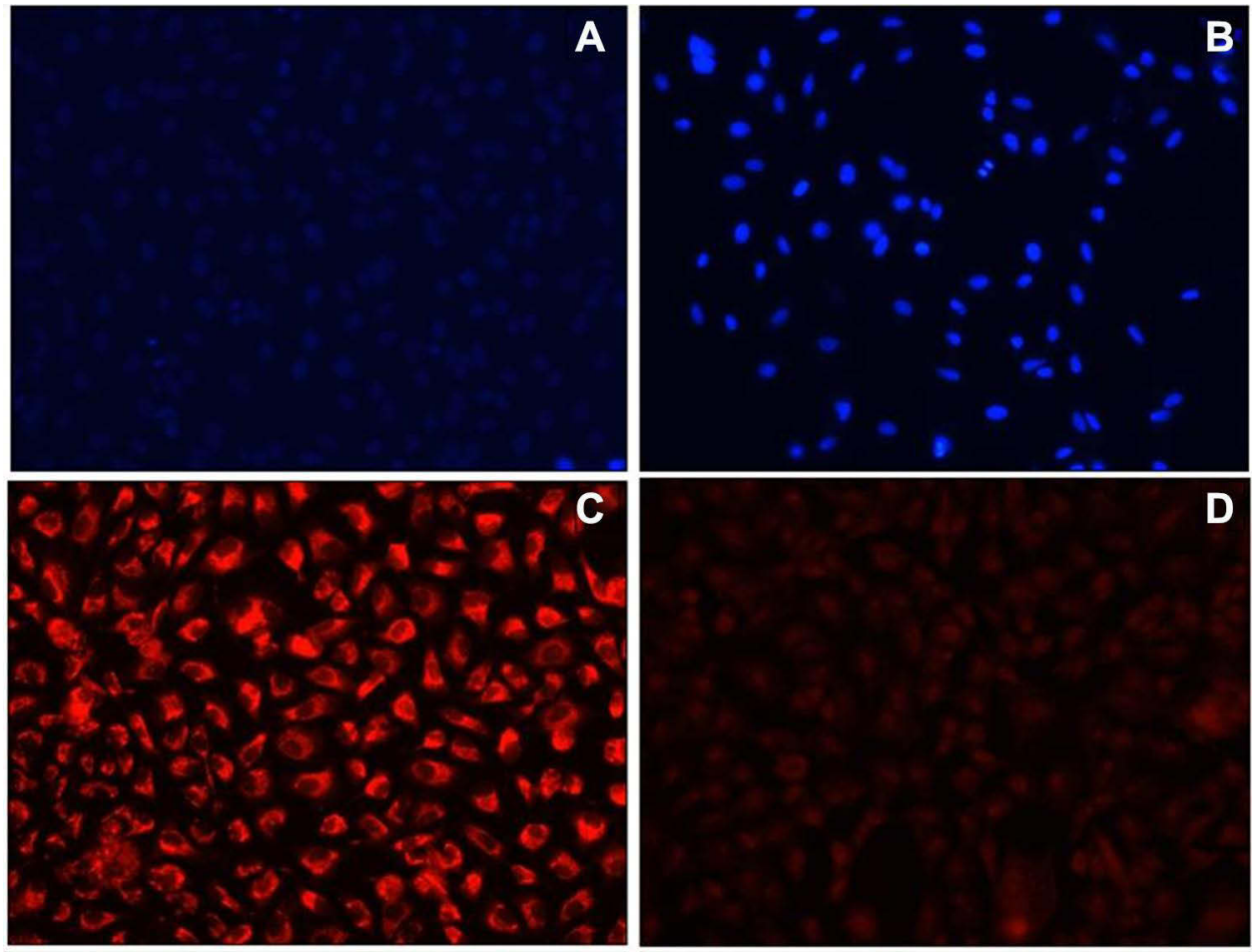

E
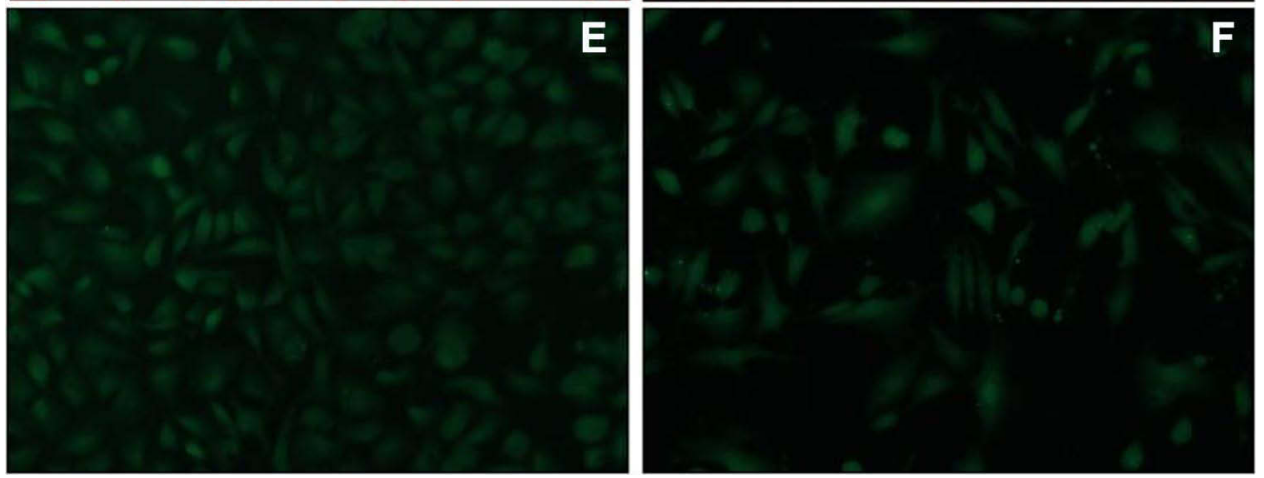

Figure 7 Images observed for AgNPs treated cells under phase contrast microscope after 48 hrs of treatment for DAPI staining (A) control (B) treated cells; for Mito Tracker Red staining (C) control (D) treated cells and for DCFDA staining (E) control (F) treated cells. 

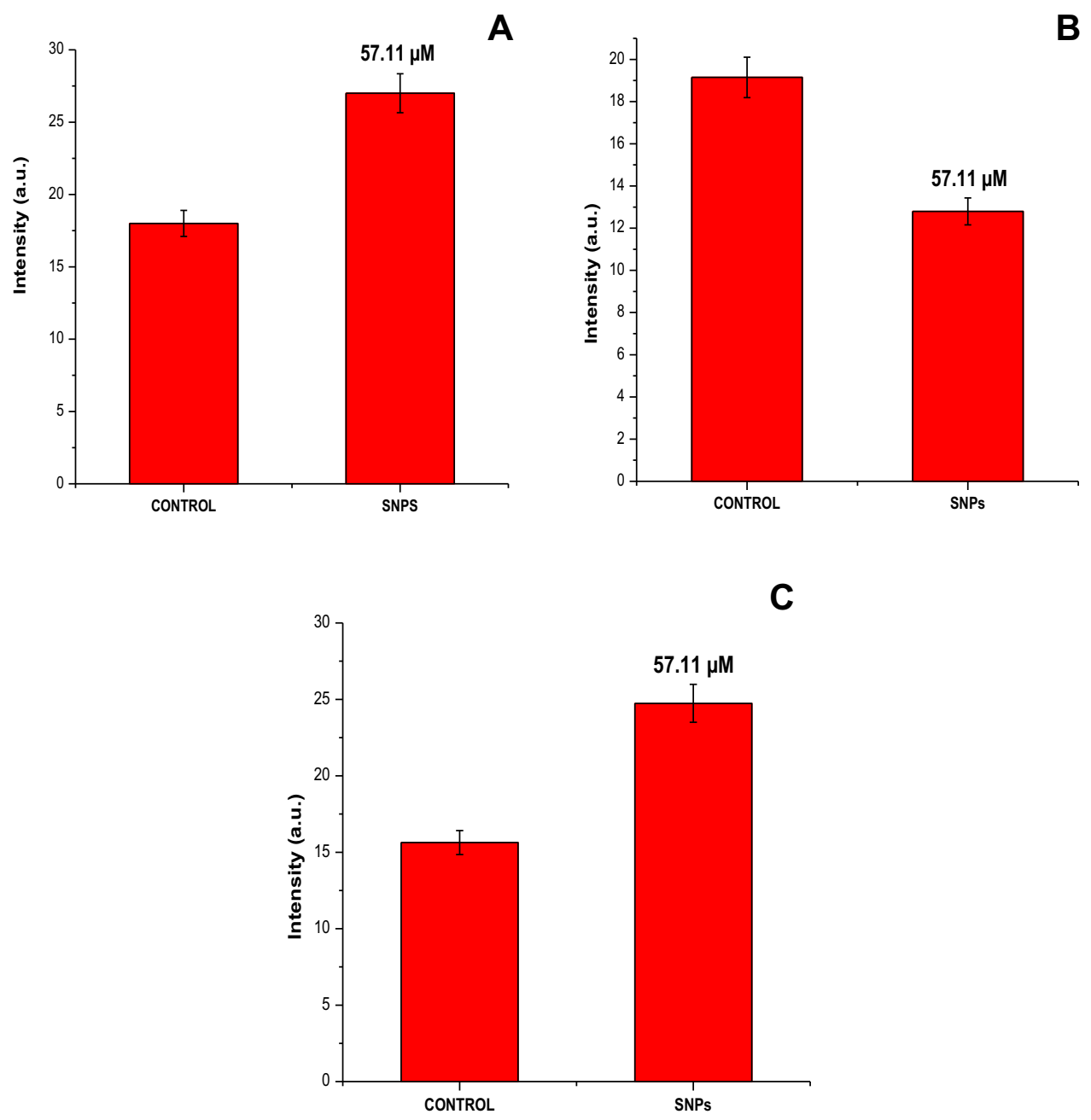

Figure 8 Graphical representation in terms of percent (A) nuclear condensation, (B) mitochondrial content, and (C) intracellular ROS generation. All the data were expressed in the mean $\pm S D$ of three experiments.

Mito Tracker Red CMX Ros. The fluorescence intensity of AgNPs treated $\mathrm{A} 549$ cells at $\mathrm{IC}_{50}$ concentration was reduced (Figure $7 \mathrm{C}$ and $\mathrm{D}$ ) in comparison to the control. The fluorescence of the treated and control cells was measured using the ImageJ software. AgNPs produced less fluorescence than the untreated cells at their corresponding IC50 (Figure 8B).

\section{Estimation of Reactive Oxygen Species of Silver Nanoparticles Treated A549 Cells}

The production of the intracellular ROS in the A549 cells after interacting with AgNPs was projected by utilizing the 5-(and 6)-carboxy-2',7'-dichlorodihydrofluorescein diacetate (DCFHDA) (Figure 7E and F). The intensity of fluorescence was relative to the measure of ROS generated in the cells. This investigation showed that AgNPs treated A549 cells (Figure 7F) demonstrated the production of greater intensity of fluorescence than the controls (Figure 7E). The biogenic AgNPs emitted brilliant fluorescence with mutilated morphological structure due to stress disrupting impact in the compactness of plasma membrane caused by ROS produced. However, untreated cells did not reveal any consideration for fluorescence and held their native morphology. ImageJ software quantified the fluorescence produced by ROS; AgNPs-treated A549 cells generated greater fluorescence than the untreated control cells (Figure 8C).

In general, anionic NPs internalize into the cells via caveolae-mediated endocytosis apart from diffusion. ${ }^{59}$ The AgNPs are released into the cytoplasm after the dissolution of caveosomes in the cells. The free NPs cause cytotoxicity by generating $\mathrm{ROS}\left(\mathrm{O}_{2}{ }^{-}, \mathrm{H}_{2} \mathrm{O}_{2}, \mathrm{OH}\right)$ due to their high surface energy, exchanging non-specifically with macromolecules. ${ }^{60}$ Living cells can neutralize intrinsic ROS, but a high level of ROS generated after the internalization of nanomaterials 
causes severe damage to the cells. ${ }^{61}$ The internalized AgNPs can disturb the mitochondrial membrane after internalization and cause damage to the key enzymes such as NADPH oxidase (Figure $7 \mathrm{C}$ and $\mathrm{D}$ ). This damage causes the release of caspase-3, which elicits the intrinsic apoptosis and kills the cells. Simultaneously, AgNPs internalize into the nucleus and causes cell death, ${ }^{62}$ which could be confirmed by DAPI (Figure 7A and B). It was also assessed that internalized AgNPs induced intracellular ROS production in A549 cells and elicited apoptosis (Figure 7E and F). The amount of production of intracellular ROS (estimated by the DCFDA method) in AgNPs treated cells increased with increasing concentration of NPs compared to control. However, an overall increase in ROS generation in mitochondria is responsible for the damage in the inner mitochondrial membrane inducing disruption.

\section{Conclusion}

We have developed a green protocol for synthesizing silver nanoparticles by using the Benincasa hispida fruit protein extract. The given silver nanoparticles were found to boost the potential of Benincasa hispida fruit protein in different bioactivities and showed effective antibiofilm, antibacterial, and anticancer activities. The mode of internalization and interaction with bacterial as well as animal cells can be a subject of further studies. The toxicity studies of silver nanoparticles have also been a matter of concern. Therefore, a detailed study of toxicity of these particles can also be a good prospect of further studies.

\section{Acknowledgment}

The authors extend their appreciation to the Researchers Supporting Project number (RSP-2021/15), king Saud University, Riyadh, Saudi Arabia.

This research was supported by Basic Science Research Program through the National Research Foundation of Korea (NRF) funded by the Ministry of Education (2020R1A6A1A03044512).

\section{Disclosure}

The authors report no conflicts of interest in this work.

\section{References}

1. Ovais M, Khalil AT, Ayaz M, Ahmad I, Nethi SK, Mukherjee S. Biosynthesis of metal nanoparticles via microbial enzymes: a mechanistic approach. Int $J$ Mol Sci. 2018;19(12):4100. doi: $10.3390 /$ ijms 19124100
2. Ahmad SA, Das SS, Khatoon A, et al. Bactericidal activity of silver nanoparticles: a mechanistic review. Mater Sci Energy Technol. 2020;3:756-759.

3. Sim W, Barnard RT, Blaskovich MAT, Ziora ZM. Antimicrobial silver in medicinal and consumer applications: a patent review of the past decade (2007-2017). Antibiotics. 2018;7(4):93. doi:10.3390/ antibiotics 7040093

4. Deore SL, Khadabadi SS, Patel QR, et al. In vitro antioxidant activity and quantitative estimation of phenolic content of Lagenaria siceraria. Rasayan J Chem. 2009;2(1):129-132.

5. Pinzaru I, Coricovac D, Dehelean C, et al. Stable PEG-coated silver nanoparticles-A comprehensive toxicological profile. Food Chem Toxicol. 2018;111:546-556. doi:10.1016/j.fct.2017.11.051

6. Guzmán MG, Dille J, Godet S. Synthesis of silver nanoparticles by chemical reduction method and their antibacterial activity. Int $J$ Chem Biomol Eng. 2009;2(3):104-111.

7. Van Dong P, Ha CH, Kasbohm J. Chemical synthesis and antibacterial activity of novel-shaped silver nanoparticles. Int Nano Lett. 2012;2(1):1-9. doi:10.1186/2228-5326-2-9

8. Tortella GR, Rubilar O, Durán N, et al. Silver nanoparticles: toxicity in model organisms as an overview of its hazard for human health and the environment. J Hazard Mater. 2020;390:121974. doi:10.1016/j.jhazmat.2019.121974

9. Elbeshehy EKF, Elazzazy AM, Aggelis G. Silver nanoparticles synthesis mediated by new isolates of Bacillus spp., nanoparticle characterization and their activity against Bean Yellow Mosaic Virus and human pathogens. Front Microbiol. 2015;6:453. doi:10.3389/fmicb.2015.00453

10. Gao Y, Chen Y, Cao Y, Mo A, Peng Q. Potentials of nanotechnology in treatment of methicillin-resistant Staphylococcus aureus. Eur $J$ Med Chem. 2020;113056. doi:10.1016/j.ejmech.2020.113056

11. Zhao Y, Chen L, Wang Y, et al. Nanomaterial-based strategies in antimicrobial applications: progress and perspectives. Nano Res. 2021;14:1-25.

12. Chen Y, Gao Y, Chen Y, Liu L, Mo A, Peng Q. Nanomaterials-based photothermal therapy and its potentials in antibacterial treatment. J Control Release. 2020;328:251-262. doi:10.1016/j.jconrel.2020.08.055

13. Yu C-H, Chen G-Y, Xia M-Y, et al. Understanding the sheet size-antibacterial activity relationship of graphene oxide and the nano-bio interaction-based physical mechanisms. Colloids Surf B Biointerfaces. 2020;191:111009. doi:10.1016/j.colsurfb.2020.111009

14. Phull A-R, Ali A, Ali A, et al. Synthesis of silver nanoparticles using euphorbia wallichii extract and assessment of their bio-functionalities. Med Chem (Los Angeles). 2020;16(4):495-506.

15. Ganguly S, Mondal S, Das P, et al. Natural saponin stabilized nano-catalyst as efficient dye-degradation catalyst. Nano-Struct Nano-Objects. 2018;16:86-95. doi:10.1016/j.nanoso.2018.05.002

16. Khan S, Rizvi SMD, Avaish M, Arshad M, Bagga P, Khan MS. A novel process for size controlled biosynthesis of gold nanoparticles using bromelain. Mater Lett. 2015;159:373-376. doi:10.1016/j. matlet.2015.06.118

17. Khan S, Rizvi SM, Saeed M, Srivastava AK, Khan M, Novel A. Approach for the synthesis of gold nanoparticles using trypsin. $A d v$ Sci Lett. 2014;20(5-6):1061-1065. doi:10.1166/as1.2014.5481

18. Xu X, Man L. Papain mediated synthesized gold nanoparticles encore the potency of bioconjugated Flutamide. Curr Pharm Biotechnol. 2021;22(4):557-568. doi:10.2174/1389201021666200227121144

19. Jayasree T, Kishore KK, Vinay M, et al. Diuretic effect of chloroform extract of Benincasa hispida rind (pericarp) in Sprague-Dawley rats. Int J Appl Biol Pharm Technol. 2011;22:94-99.

20. Dong MY, Lu M, Yin Q, Feng W, Xu J, Xu W. Study of Benincasa hispida contents effective for protection of kidney. Liangsu J Agr Sci. 1995; 11:46-52.

21. Shih C-YT, Wu J, Jia S, Khan AA, Ting K-LH, Shih DS. Purification of an osmotin-like protein from the seeds of Benincasa hispida and cloning of the gene encoding this protein. Plant Sci. 2001;160 (5):817-826. doi:10.1016/S0168-9452(00)00450-7 
22. Atiwetin P, Harada S, Kamei K. Serine proteinase inhibitor from wax gourd (Benincasa hispida [Thunb] Cogn.) seeds. Biosci Biotechnol Biochem. 2006;70(3):743-745. doi:10.1271/bbb.70.743

23. Zaini NAM, Anwar F, Hamid AA, Saari N. Kundur [Benincasa hispida (Thunb.) Cogn.]: a potential source for valuable nutrients and functional foods. Food Res Int. 2011;44(7):2368-2376. doi:10.1016/j.foodres.2010.10.024

24. Qadrie ZL, Hawisa NT, Khan M, Ali W, Samuel M, Anandan R. Antinociceptive and anti-pyretic activity of Benincasa hispida (Thunb.) cogn. in Wistar albino rats. Pak J Pharm Sci. 2009;22(3):45.

25. Shakya A, Bhat HR, Ghosh SK. Assessment of neurobehavioral properties of hydroalcoholic extract of Benincasa hispida (Thunb.) Cogn. Fruit Pulp in Mice. J Biol Act Prod Nat. 2019;9 (4):299-310.

26. Sabale V, Kunjwani H, Sabale P. Formulation and in vitro evaluation of the topical antiageing preparation of the fruit of Benincasa hispida. $J$ Ayurveda Integr Med. 2011;2(3):124. doi:10.4103/09759476.85550

27. Jiang X, Kuang F, Kong F, Yan C. Prediction of the antiglycation activity of polysaccharides from Benincasa hispida using a response surface methodology. Carbohydr Polym. 2016;151:358-363. doi:10.1016/j.carbpol.2016.05.079

28. Nadhiya K, Vijayalakshmi K, Gaddam ARG, Reddy G. Antiobesity effect of Benincasa hispidaFruit extract in high fat diet fed Wistar albino rats. Int J Pharm Clin Res. 2016;8(12):1590-1599.

29. Gill NS, Dhiman K, Sharma P, et al. Evaluation of free radical scavenging and antiulcer potential of methanolic extract of Benincasa hispida seeds. Res J Med Plant. 2011;5(5):596-604. doi:10.3923/rjmp.2011.596.604

30. Yenda B, Rao BV, Rao BG. In vitro antioxidant activity studies on leaves of Benincasa hispida (Thunb.) Cogn. Res J Pharm Biol Chem Sci. 2014;5:141-147.

31. Huang H, Huang J, Tso TK, Tsai Y, Chang C. Antioxidant and angiotension-converting enzyme inhibition capacities of various parts of Benincasa hispida (wax gourd). Food/Nahrung. 2004;48 (3):230-233. doi:10.1002/food.200300428

32. Varghese HS, Kotagiri S, Vrushabendra SBM, Archana SP, Raj GG. Nephroprotective activity of Benincasa hispida (Thunb.) Cogn. fruit extract against paracetamol induced nephrotoxicity in rats. Res J Pharm Biol Chem Sci. 2013;4(1):322-332.

33. Lee K-H, Choi H-R, Kim C-H. Anti-angiogenic effect of the seed extract of Benincasa hispida Cogniaux. J Ethnopharmacol. 2005;97 (3):509-513. doi:10.1016/j.jep.2004.12.008

34. Natarajan D, Lavarasan RJ. Antimicrobial studies on methanol extract of Benincasa hispida cogn., fruit. Anc Sci Life. 2003;22(3):98.

35. Moon MK, Kang DG, Lee YJ, Kim JS, Lee HS. Effect of Benincasa hispida Cogniaux on high glucose-induced vascular inflammation of human umbilical vein endothelial cells. Vascul Pharmacol. 2009;50 (3-4):116-122. doi:10.1016/j.vph.2008.11.007

36. Wingfield PT. Protein precipitation using ammonium sulfate. Curr Protoc Protein Sci. 2016;84(1):A-3F. doi:10.1002/0471140864. psa03fs 84

37. Khan S, Ahmad K, Ahmad A, et al. Biogenic pentagonal silver nanoparticles for safer and more effective antibacterial therapeutics. Int J Nanomedicine. 2018;13:7789. doi:10.2147/IJN.S168224

38. Iram S, Zahera M, Wahid I, et al. Cisplatin bioconjugated enzymatic GNPs amplify the effect of cisplatin with acquiescence. Sci Rep 2019;9(1):1-16. doi:10.1038/s41598-019-50215-y

39. Khan MS, Siddiqui SA, Siddiqui MSRA, Goswami U, Srinivasan KV, Khan MI. Antibacterial activity of synthesized 2, 4, 5-trisubstituted imidazole derivatives. Chem Biol Drug Des. 2008;72 (3):197-204. doi:10.1111/j.1747-0285.2008.00691.x

40. Baker A, Syed A, Alyousef AA, et al. Sericin-functionalized GNPs potentiate the synergistic effect of levofloxacin and balofloxacin against MDR bacteria. Microb Pathog. 2020;148:104467. doi:10.1016/j.micpath.2020.104467
41. Kalishwaralal K, BarathManiKanth S, Pandian SRK, Deepak V, Gurunathan S. Silver nanoparticles impede the biofilm formation by Pseudomonas aeruginosa and Staphylococcus epidermidis. Colloids Surf B Biointerfaces. 2010;79(2):340-344. doi:10.1016/j. colsurfb.2010.04.014

42. Baker A, Wahid I, Hassan Baig M, et al. Silk cocoon-derived protein bioinspired gold nanoparticles as a formidable anticancer agent. J Biomed Nanotechnol. 2021;17(4):615-626.

43. Leite FL, Bueno CC, Da Róz AL, Ziemath EC, Oliveira ON. Theoretical models for surface forces and adhesion and their measurement using atomic force microscopy. Int J Mol Sci. 2012;13 (10):12773-12856

44. Huang J, Li Q, Sun D, et al. Biosynthesis of silver and gold nanoparticles by novel sundried Cinnamomum camphora leaf. Nanotechnology. 2007;18(10):105104. doi:10.1088/0957-4484/18/ 10/105104

45. Soliman WE, Khan S, Rizvi SMD, et al. Therapeutic applications of biostable silver nanoparticles synthesized using peel extract of Benincasa hispida: antibacterial and anticancer activities. Nanomaterials. 2020;10(10):1954. doi:10.3390/nano10101954

46. Krutyakov YA, Kudrinskiy AA, Olenin AY, Lisichkin GV. Synthesis and properties of silver nanoparticles: advances and prospects. Russ Chem Rev. 2008;77(3):233. doi:10.1070/RC2008v077n0 3ABEH003751

47. Jena P, Bhattacharya M, Bhattacharjee G, et al. Bimetallic gold-silver nanoparticles mediate bacterial killing by disrupting the actin cytoskeleton MreB. Nanoscale. 2020;12(6):3731-3749. doi:10.1039/ C9NR10700B

48. Rai MK, Deshmukh SD, Ingle AP, Gade AK. Silver nanoparticles: the powerful nanoweapon against multidrug-resistant bacteria. $J \mathrm{Appl}$ Microbiol. 2012;112(5):841-852. doi:10.1111/j.1365-2672.20 12.05253.x

49. Liao S, Zhang Y, Pan X, et al. Antibacterial activity and mechanism of silver nanoparticles against multidrug-resistant Pseudomonas aeruginosa. Int J Nanomedicine. 2019;14:1469. doi:10.2147/IJN. S191340

50. Shrivastava S, Bera T, Roy A, Singh G, Ramachandrarao P, Dash D. Characterization of enhanced antibacterial effects of novel silver nanoparticles. Nanotechnology. 2007;18(22):225103. doi:10.1088/ $0957-4484 / 18 / 22 / 225103$

51. Mirzajani F, Ghassempour A, Aliahmadi A, Esmaeili MA. Antibacterial effect of silver nanoparticles on Staphylococcus aureus. Res Microbiol. 2011;162(5):542-549. doi:10.1016/j. resmic.2011.04.009

52. Joo H-S, Otto M. Molecular basis of in vivo biofilm formation by bacterial pathogens. Chem Biol. 2012;19(12):1503-1513. doi:10.1016/j.chembiol.2012.10.022

53. Park H-J, Kim HY, Cha S, et al. Removal characteristics of engineered nanoparticles by activated sludge. Chemosphere. 2013;92 (5):524-528. doi:10.1016/j.chemosphere.2013.03.020

54. Ehrlich GD, Arciola CR. From Koch's postulates to biofilm theory. the lesson of bill costerton. Int J Artif Organs. 2012;35:695-699. doi:10.5301/ijao.5000169

55. Maira-Litrán T, Bentancor LV, Bozkurt-Guzel C, O’Malley JM, Cywes-Bentley C, Pier GB. Synthesis and evaluation of a conjugate vaccine composed of Staphylococcus aureus poly-N-acetylglucosamine and clumping factor A. PLoS One. 2012;7(9):e43813. doi:10.1371/journal.pone.0043813

56. Al-Sheddi ES, Farshori NN, Al-Oqail MM, et al. Anticancer potential of green synthesized silver nanoparticles using extract of nepeta deflersiana against human cervical cancer cells (HeLA). Bioinorg Chem Appl. 2018;2018:1-12. doi:10.1155/2018/9390784

57. Gurunathan S, Lee K-J, Kalishwaralal K, Sheikpranbabu S, Vaidyanathan R, Eom SH. Antiangiogenic properties of silver nanoparticles. Biomaterials. 2009;30(31):6341-6350. doi:10.1016/j. biomaterials.2009.08.008 
58. Mollick MMR, Rana D, Dash SK, et al. Studies on green synthesized silver nanoparticles using Abelmoschus esculentus (L.) pulp extract having anticancer (in vitro) and antimicrobial applications. Arab J Chem. 2019;12(8):2572-2584. doi:10.1016/j.arabjc.2015.04.033

59. Chithrani BD, Ghazani AA, Chan WCW. Determining the size and shape dependence of gold nanoparticle uptake into mammalian cells. Nano Lett. 2006;6(4):662-668. doi:10.1021/n1052396o

60. Valko M, Leibfritz D, Moncol J, Cronin MTD, Mazur M, Telser J. Free radicals and antioxidants in normal physiological functions and human disease. Int J Biochem Cell Biol. 2007;39(1):44-84.
61. Yan L, Gu Z, Zhao Y. Chemical mechanisms of the toxicological properties of nanomaterials: generation of intracellular reactive oxygen species. Chem Asian J. 2013;8(10):2342-2353. doi:10.1002/ asia.201300542

62. Sharma P, Jha AB, Dubey RS, Pessarakli M. Reactive oxygen species, oxidative damage, and antioxidative defense mechanism in plants under stressful conditions. J Bot. 2012;2012. 55

\section{Publish your work in this journal}

The International Journal of Nanomedicine is an international, peerreviewed journal focusing on the application of nanotechnology in diagnostics, therapeutics, and drug delivery systems throughout the biomedical field. This journal is indexed on PubMed Central, MedLine, CAS, SciSearch ${ }^{\mathbb{R}}$, Current Contents ${ }^{\mathbb{R}} /$ Clinical Medicine, $^{-}$
Journal Citation Reports/Science Edition, EMBase, Scopus and the Elsevier Bibliographic databases. The manuscript management system is completely online and includes a very quick and fair peer-review system, which is all easy to use. Visit http://www.dovepress.com/ testimonials.php to read real quotes from published authors. 